ISSN : 1412-7601

Volume 3, No.1 Maret 2017

http://www.ekonobis.unram.ac.id

EKONOBIS

\title{
A Scenario Study of Investment: Portfolio Modeling Through Simulation on Virtual Management Funding Corporation
}

\section{Baiq Nurul Suryawati}

Universitas Mataram

\begin{tabular}{l|l}
\hline A R T I C LE I N F O & Received : 25 Des 2016; Accepted: 20 Februari 2017; Published: Maret 2017 \\
\hline $\begin{array}{l}\text { Keywords : } \\
\text { Investment, Portfolio } \\
\text { Modeling; Scenario Study }\end{array}$ & $\begin{array}{l}\text { ABSTRACT : This investment scenario study was created with the help of a virtual } \\
\text { company engaged in investment management, called UoM Fund Management } \\
\text { Corportation. The simulation with the establishment of this virtual company will } \\
\text { facilitate the application and understanding of various portfolio theory and modeling. It } \\
\text { is recommended to investors to divide their investment activities into three categories, } \\
\text { Strategy Determinants (Team S), Alpha or Advantage (A) Finders, and Quantitative } \\
\text { Research Assessors (Q). This division of activities is expected to maximize the profits of } \\
\text { investors. }\end{array}$ \\
\hline $\begin{array}{l}\text { Kata kunci: } \\
\text { Investasi;Permodelan } \\
\text { Portfolio; StudiSkenario }\end{array}$ & $\begin{array}{l}\text { yang bergerak di bidang manajemen investasi, yang disebut UoM Fund Management } \\
\text { memudahkan penerapan dan pemahaman berbagai macam teori portofolio dan } \\
\text { permodelannya. Direkomendasikan kepada para investor untuk membagi kegiatan } \\
\text { investasi mereka dalam tiga kategori, Penentu Strategi (Tim S), Pencari Alpha atau } \\
\text { Keuntungan (A), dan Penilai Riset Kuantitatif (Q). Pembagian aktivitas ini ditengarai akan } \\
\text { memaksimalkan keuntungan para investor. }\end{array}$ \\
\hline
\end{tabular}

Corresponding Author :

Alamat : Program Studi Ekonomi Pembangunan, Fakultas Ekonomi dan Bisnis, Universitas Mataram, Jln. Majapahit No. 62 Mataram.

e-mail: bqnurul@gmail.com 


\section{INTRODUCTION}

Virtual management-funding corporation created as we call it UoM Fund Management Corporation (UFMC). It is a virtual management-funding corporation design to fund by Australian institution. The simulation consist the institution as a trustworthy foundation managed by energetic and full of spirit young professional people. This organization maintains their objective by investing in financial market and gets the benefit from excess return to increase their client wealth. It has $\$ 40$ billion to invest in financial asset for 15-20 years. A scenario study will conduct through simulation that applies various portfolios modeling by theory as guidance. Firstly, it defines objective, philosophy, strategies and planning based on theories of portfolio, decision of asset allocation with share market evaluation, explanation of investment in shares and bonds, and its recommendation.

\section{Investment Objective}

The main objective is to maximize the return for investor at a given level of risk based on their risk preference in long-term period. We also want to get the maximum benefit from the nature of the fund.

\section{Investment Philosophy}

The Efficient Market Hypothesis asserts that the price in the market is unbeatable because all information is reliable and already reflected in the price. However, the further research shown that there is inefficiency in market. Some anomalies founded against this theory that are the share prices too volatile, predictable and move not only due to reaction to news.

Subsequently, investors systematically practice irrational behaviours in the market, such as explained by the Behavioural Finance Theory. Investors involve subjectivity on their judgement based on personal beliefs, perception, and educational background. Two basic ideas in this theory are mispricing and market timing that creates opportunities to gain excess returns by exploiting the market. Based on these considerations, we believe that active investment will lead us to achieve our objectives. Elton et.all (2003) define the active investment management as the way investors respond to market by making forecast they made instead of using the index per se. However, in practice we will use Market Neutral investing approach to outperform the market.

\section{Investment Strategies and Planning}

In line with our philosophy, we actively manage our portfolio by using accurate techniques that optimize the return of portfolio. Unfortunately, it is more costly than passive investment. Therefore, we also attempt to manage the cost at minimum level so it will give optimal return. In this section, we will explain our investment strategies including investing in equities and bonds.

\section{Efficient Frontier}

The efficient frontier is a convex graph that illustrates the intersection between the minimum variance and the maximum return of set of portfolios. This graph represents the best combination of risk and expected return. Therefore, all portfolios, which lie on the efficient frontier, will be optimal.

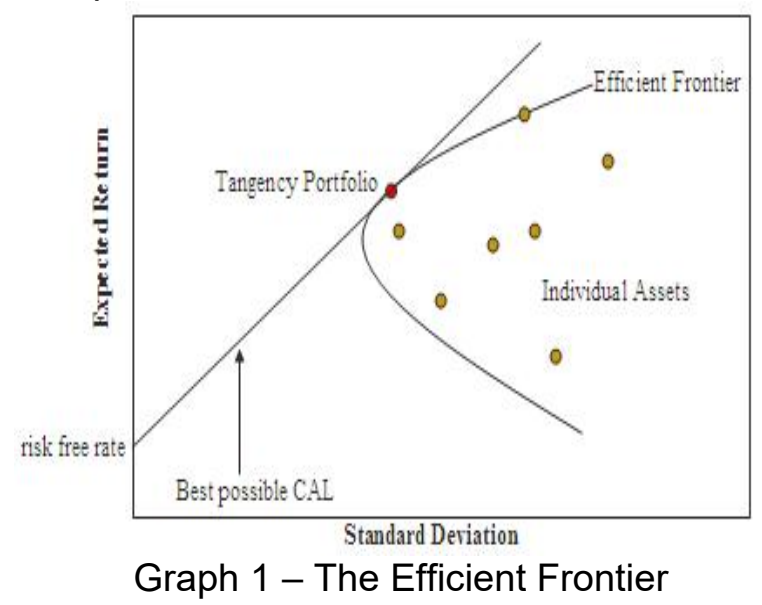

\section{CAPM}

As a model of equilibrium, CAPM explains the relationship between risk and expected return that assumes investors must be reward with risk free rate for time value of money and risk premium for taking additional risk. This model recognizes the possibility for investors to choose the efficient frontier to obtain the optimal portfolio, 
which maximize investors' wealth. Instead of the simplicity, CAPM is common to use as basic for other methods profound to calculate or valuating equity.

\section{Estimating Market Return Using CAPM}

The expected return could obtain by averaging the frequency distribution of expected return. In line with this, CAPM assumes that investors have homogenous expectation of probability distribution of future returns. Therefore, they hold the same portfolio of risky assets in order to seek the same efficient set of optimal portfolios. In equilibrium, CAPM identified this optimal portfolio as market portfolio (the tangency of efficient frontier and risk free), which lies on the Capital Market Line.

The Capital Market Line represents the combination of market expected return and variance. CAPM formulates the expected return in to this formula:

$$
\overline{R_{i}}=R_{f}+\left(\frac{\overline{R_{M}}-R_{f}}{\sigma_{M}^{2}}\right) \sigma_{i M}
$$

\section{Estimating Risk Using CAPM}

Based on the CAPM assumption, the expected return is performed by risk free asset in the market, beta that measure the sensitivity of that asset and its risk, which is known as systematic risk. Furthermore, we used linear regression to calculate beta, the judgment to use this calculation because there is a linear relationship between risk and return. By this statement, investors realize that as an increase in risk result an increase in return. In equilibrium, CAPM identified that the expected returns and systematic risk have linear relationship that reflected in Security Market Line.

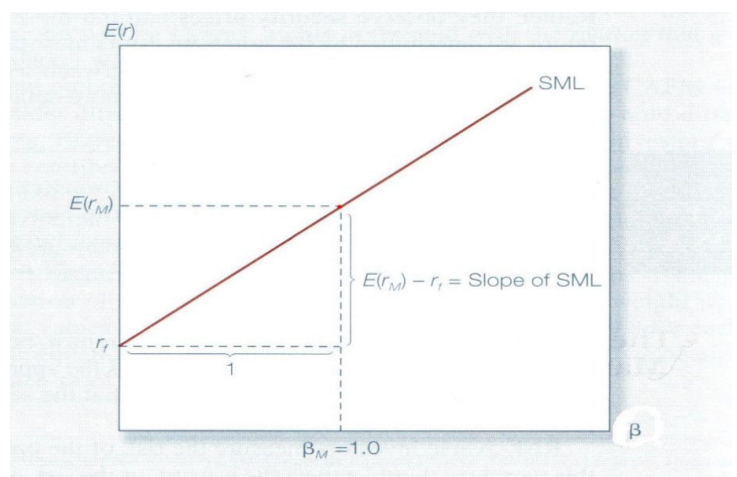

Graph 3 - Security Market Line

The formulae of CAPM in this case SML could found through the calculation below:

$$
\overline{R_{i}}=R_{f}+\beta_{i}\left(\overline{R_{M}}-R_{f}\right)
$$

\section{Asset Allocation}

As our approach for investing is Market Neutral investing, we want to look for financial market and companies with a lot of opportunity for misprising to occur. Furthermore, it will help us to identify the potential market in the world as opportunity of mispricing could happen due to a large number of transactions in inefficient market. We allocated our funds on two kinds of financial assets, which are bonds and shares. This approach takes to exploit the inefficiency market of financial market. Moreover, by investing in bond market will give us a sustainable income. Sustainable incomes reach as the fact that bond market performs a fixed interest.

Our philosophy as an active investment in order to outperform the market fulfil by setting the investment time horizon as well as investor's goals. In general, we are aiming to give an expected rate of investment return, which exceeds the inflation rate. For this reason, we decide a benchmark for our portfolio. Hence, our investment policy established as the table below:

\begin{tabular}{|l|l|}
\hline \multicolumn{1}{|c|}{ Asset types } & \multicolumn{1}{c|}{ Benchmarks } \\
\hline Australian share & S \& P 50 index \\
\hline Chinese share & SSE 50 index \\
\hline Indian share & S \& P CNX Nifty \\
\hline $\begin{array}{l}\text { Indonesian } \\
\text { bond }\end{array}$ & $\begin{array}{l}\text { SUN (Surat } \\
\text { Utang Negara) }\end{array}$ \\
\hline
\end{tabular}


With this combination, investors will have alternatives of some specialised fund according to their preference. From day to day, we also will review and assess the assets in our portfolio using our performance management team.

\section{Share Market Evaluation}

The next section will describe the main reason as a background for investing in India, China, Australia Share Market and Indonesia Bond Market.

\section{a. Invest in China Share Market}

Two big financial markets in China are Shanghai and Shenzhen Stock Exchange shown a big improvement in number of transaction trading. Both of these markets seemingly inefficient and it give opportunity for investors to diversify the portfolio and get benefit from it. The inefficiency of these markets due to fact that shares traded are mainly belongs to government public organization. As its immature regulation, we will react actively by doing short sell in the market.

b. Invest in India Share Market

Beside china, India share market also shown a significant increase and become one of the fastest growths emerging market. A large number of Indian people especially middle class as sources of human resource potency will support their continuously growth. India is a democratic country with relatively stable political situation this fact suitable for an improvement of investment. Economic growth in India predicted to continue increase as many strong multinational companies emerge.

c. Invest in Australia Share Market Australian share market is one of develop market in the world. Within this market, many shares from high growth and value companies traded such Woolworth, Coles Myer, BHP Billiton, etc. These kinds of 'blue chip company' offer high return that we have planning to invest in this company and use S\&P 50 index as benchmark for liquid shares. Another consideration to choose Australian market is due to fact that our client tend to be feel more safety, being familiar with the regulation and no currency adjusted that could cause another risk.

d. Invest in Indonesia Bonds Market

As one of developing country in Southeast Asia, Indonesian has the largest market within this area. A massive opportunity provide by the government for foreign investor. Indonesian economy at this moment shows a significant growth around $5.5 \%$ per year. Moreover, Indonesian natural resources and an increasing in number of middle-upper class people in Indonesian will support Indonesian growth for the future. We focused investing in government market as it coupon rate offers $12.5 \%-14 \%$ return.

\section{How to Invest in Shares}

a) Stock Valuation

Stocks are valued with Two Stage Dividend Discount Model, one model used in Discounted Cash Flow valuation approach. In this model, we assume that dividends will grow at an amazing growth for some period before it moves to one constant growth rates. This model is likely to be realistic. Although it is quite simple, it includes more than one growth rate in a stock's life and estimated initial period that will strengthen the value we get. This model could formulate as:

$$
P=D_{1}\left[\frac{1-\left(\frac{1+g_{1}}{1+k}\right)^{N}}{k-g_{1}}\right]+\left[\frac{D\left(1+g_{1}\right)^{N-1}\left(1+g_{2}\right)}{\left(k-g_{2}\right)}\right]\left[\frac{1}{(1+k)^{N}}\right]
$$

\section{b) Stock Selection}

After identifying the expected return and beta using CAPM, we need to select the stocks that give the highest profit. Then, we compare expected return from 
CAPM with the supposed actual returns to find mispriced equities. Alpha is the difference between the equilibrium expected return and the expected return because of mispricing. We seek positive alpha equities to buy and negative alpha to sell in order to beat the market. We can construct new efficient frontier from security with positive alpha (stock A) that outperform the market portfolio (M). Therefore, we get new portfolio $\mathrm{P}$ by optimizing the market portfolio and mispriced equities.

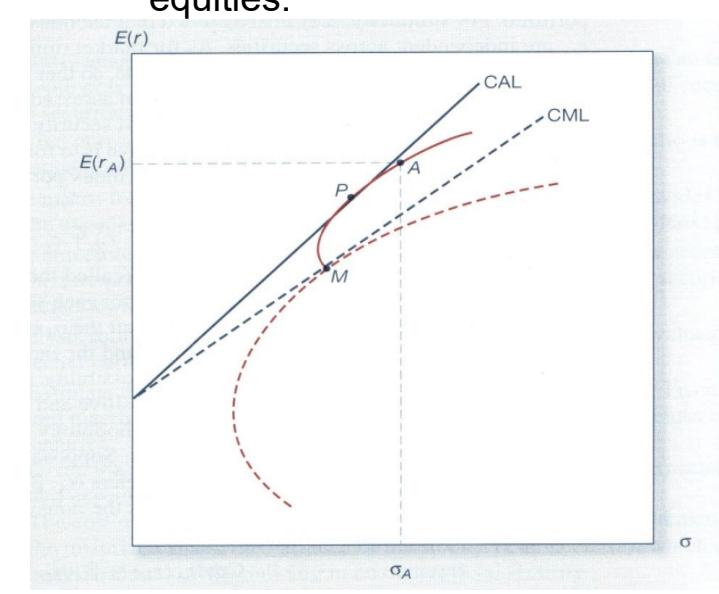

Graph 4 - Optimized Portfolio Constructed From Mispriced Equities

\section{How to Invest in Bonds}

\section{a. Bonds Valuation}

In general, the bond valuations calculate to determine the present value of future cash flow of bonds, which discounted at the required rate of return.

$$
V_{b}=\sum_{t=1}^{N} \frac{\frac{\$ I_{t}}{2}}{\left(1+\frac{k_{b}}{2}\right)^{t}}+\frac{\$ M}{\left(1+\frac{k_{b}}{2}\right)^{2 N}}
$$

Yield to Maturity reflects the internal rate of return for investors that earned by holding bonds until maturity. It assumed that the all cash flow from the bonds reinvested until the bonds mature.

The changes in interest rates influence the price of bonds. This sensitivity of price of bonds can measure by duration and convexity since this combination provides better approximation of price changes due to interest rate changes.

$$
\begin{aligned}
D & =\frac{1}{2} \frac{1}{P} \sum_{t=1}^{2} \frac{t C(t)}{\left(1+\frac{r}{2}\right)^{t}} \\
C & =\frac{1}{2} \frac{1}{P} \sum_{t=1}^{T} \frac{t(t+1) C(t)}{(1+r)^{t}}
\end{aligned}
$$

The sensitivity of bonds price can calculate with this formula:

$$
\frac{d P}{P}=-D \frac{d(1+r)}{(1+r)}+C\left(\frac{d(1+r)}{(1+r)}\right)^{2}
$$

As an active bond management, we will forecast the aggregate interest rate to determine the unexpected changes in yield curves, including the shift in level, slope and curvature, then remove the unexpected changes in order to gain benefit from interest rates movement.

\section{b. Bonds Selection}

In most cases, bonds are select based on the credit rating. However, as an active management, we seek the mispriced bonds in order to get benefit from bonds with different default probabilities from the credit ratings. We compare prices in the markets to choose the underpriced securities by using the current spot rates. We swap the mispriced bonds based on the yield curve by selling of one bond then using the proceeds to buy other bonds. The yield curve determined through current market data estimation. In this stage, the bonds swept by selling bonds with higher values and using the proceeds for buying bonds with lower values.

We also recognize that the interest rate might fluctuate because of the change in economic growth, inflation rate, etc. Our bond manager will forecast the future interest rate based on the macroeconomic data. To deal with this problem, we use the duration 
and convexity of bonds to value whether the securities are undervalued or overvalued. However, forecasting may not cover the change in interest rate. If something happens in interest rate, such as the increase in interest rate, we will sell the longer duration bond and buy the shorter one to reduce the duration of the portfolio. If interest rate declines anticipated, managers will increase portfolio duration.

\section{Performance Evaluation}

As previously, it mention we used benchmark as our guidelines and the measurement tool to evaluate our performance. However, unlike passive investors, we use benchmark as source of forecasting the CAPM model. We will evaluate our performance on semester basis. Consistently with CAPM, we will forecast our efficient frontier and continuously controls the return we get from diversifying our optimal portfolio. If the return we achieve as high as benchmark or outperform the benchmark we will consider to stick with it but if not, we will evaluate it.

\section{RECOMMENDATION}

To optimize the efficiency of our corporation performance we will use the teams set by the management. They are the Strategy ('S') team that will encompass their duty from identifying the clients' objective and help to find the most suitable alternatives to beat the market, consistently with it the Alpha ('A') team will use growth investing approach and significantly contribute in portfolio selection process by providing accurate analysis about the market. The ' $A$ ' team identify and look for the companies with above average growth. The last team is quantitative (' $Q$ ') team. The ' $Q$ ' team conducts quantitative research to identify the companies' securities within the selected countries based on their business fundamentals. This team also do the market forecast to support the alpha team.

\section{BIBLIOGRAPHY}

Elton EJ, Gruber MJ, Brown SJ \& Goetzmann WN, 2003, Modern Portfolio Theory and Investment Analysis, $6^{\text {th }}$ ed., John Wiley \& Sons, Inc, U.S.A.

Cocks G, 2007, The Fundamental Portfolio Management Lecture Note.

Investopedia, Modern Portfolio Theory, viewed 7 July 2007, from <http://www.investopedia.com/articles/06/MPT.asp/>.

Sifma, Bonds Investing Strategy, viewed 10 July 2007, from <http://www.investinginbonds.com/learnmore. asp?catid=6\&id=386>.

The Investment Process, viewed 10 July 2007, from http://pages.stern.nyu.edu/ adamodar/New Home Page/invmgmt/invmgt1.htm/

Indian Economic Overview, viewed 19 July 2007, from http://www.economywatch.com/indianeconomy/indian-economy-overview.html

GDP Growth, viewed 19 July 2007, from http://www.usembassyjakarta.org/econ/GDP\%20Growth\%203Q-website.pdf

Australian Bureau Statistic, viewed 19 July 2007, from<http://www.abs.gov.au/AUSSTATS/abs@.nsf/Latestproducts/1309.0Main\%20Features 42007?opendocument\&tabname=Summary \&prodno=1309.0\&issue=2007\&num=\&view 